\title{
ZALĄŻKI OGÓLNOKOŚCIELNEJ DYSCYPLINY DUCHOWIEŃSTWA W ŚWIETLE POSTANOWIEŃ I SOBORU NICEJSKIEGO (325)
}

Uogólnia się zazwyczaj pogląd, że ze względu na prześladowania chrześcijan do IV w. niewiele dokonano w Kościele na polu uformowania własnego, odrębnego porządku prawnego. Jest w tyti dużo prawdy, ale i sporo uproszczenia. Sobór Nicejski I /325/ był niezwykle ważnym wydarzeníem także w tej dziedzinie 1 jest doniosłym źródłem poznawczym. Obok sporzituzenia Symbolu wiary dokonal on bezprecedensowego podsunowania kościelnego prawa zwyczajowego oraz pisanego prawa partykularnego, istniejącego już w Kościele, a także wniósł do niego własne elementy, mające w jego pojęciu najlepiej służyć przyszłościowej wizji rozwoju Królestwa Chrystusowego na ziemi. Powstał w ten sposób po raz pierwszy w skali ogólnokościelnej jakiś wspólny model prawny życia chrześcijańskiego, w jego najważniejszych przejawach zewnętrzno - społecznych. Określamy go dziś mianem d y s c y p 1 i n y $k$ o ś $c i$ e 1 n e j, zawierającej całościowy system praw i obowi ązków, które obok prawa Bożego nakłada swoim podwładnym kompetentna władza kościelna. Dyscyplina ta ma oczywiście cel zbawczy, uświęcający. Kościół ukazuje w niej konkretną droge realizacji prawa naturalnego 1 objawionego prawa Bozego, dostosowaną do warunków przestrzeni i czasu.

ojcowie Soboru Nicejskiego I w 20 kanonach $^{1}$ dyscyplinarnych wydali liczne ustawy, w których rozstrzygnęli wiele nabrzmiałych problemów ówczesnego Kościoła. Nieḱtóre z tỵch ustaw miały charakter

1 Przyjęcie w Nicei przez Ojców Soboru nazwy "canon" dla dyscyplinarnych ustaw kościelnych stało się z czasem rozstrzygającym kryterium dla określenia ustawodawstwa kościelnego mianem "prawa kanonicznego", w odróżnieniu od ustawodawstwa świeckiego. Por. G. Michiels, Normae generales iuris canonici, I, Parisis $1949,7-9$. 
doraźny, odnosiły się do konkretnych sytuacjl tamtych czasów 1 wraz z nimi przeminęły. Taki charakter miał sposób postępowania z "lapsi", tzn. z chrześcijanami, którzy podczas prześladowań zaparli się wia$r y^{2}$. Inne natomiast, z natury ogólniejsze, chociaż były jeszcze później zmieniane $i$ uściślane, wytrzymały jednak próbę czasu w swych koncepcyjnych treściach, stając się trwałym fundamentem ustroju Kościoła.

Do nicejskich ustaw, zasługujących na miano t $r$ w a $¥$ y $c h$ z a 1 ą ż k ó w o g ó l n o k o śc 1 e l n e j d y s c y p 1 1ny, należą bez wątpienia norny, które stworzyły ważkie elementy organizacyjne dla postawy 1 działalności duchowieństwa. Jedne z nich wchodzą wana strukturę ustroju hierarchicznego duchowieństwa, inne zaś wskazują na powinności stanowe duchownych. Poddamy tu więc krótkiej refleksji jedną 1 drugą grupę ustaw, a mianowicie:

- normy określające strukturę ustrojową duchowieństwa,

- normy ustanawiające obowiazki duchownych ${ }^{3}$.

I. NORMY OKHESLAJACE STRUKTURE USTROJOWA DUCHOWIENSTWA

W początkach IV w. ustrój konstytucyjny Kościoła charakteryzował się znacznym rozwojem. Duchowni stanowili już wyraźnie odrębny stan od świeckich wiernych, obok zaś jednych i drugich wyrastał stan ludzi żyjących według rad ewangelicznych, a więc anachoretów, ascetów, mnichów ${ }^{4}$. Terytorialnie, z pierwotnych gmin chrześcijańskich powstały już, przez analogię do ustroju Imperium Rzymskie-

2 Problem ludzi "upadłych" istniał w Kościele już wcześniej, a w III w. był żywo dyskutowany, jak należy z nimi postępować 1 czy moźna 1ch po surowej pokucie włączać znów do społeczności kościelnej. Por. D. Rops, Kościól pierwszych wieków, tłum. K。 Ostrowska, Warszawa 1968, 349-395.

3 Przy cytowaniu kanonów posługiwać się będziemy 1 ch łacińskim przekładem Dionizego Mniejszego, zamieszczonym w zbiorze J. D. Mansiego, Sacrorum Conciliorum nova et amplissima collectio/Parisiis 18992, repr.Graz 1960, II, 677-684/ po skonfrontowaniu go z krytycznym opracowaniem Ch. J. Hefele'go, Histoire des conciles, Paris 1907, I 1 , 528-620.

4 Por. H. E. Feine, Kirchliche liechtsgeschichte, Bd. 1: Die kathol1sche Kirche, Weimar 1955, 42-46, 73-76. 
go ${ }^{5}$, prowincje kościelne/metropolie/ oraz zaczęły się kształtować późniejsze parafie $i$ diecezje. Jednakże w czasie Soboru Nicejskiego I ani diecezje, ani parafie nie miały jeszcze prawnie skrystalizowanego oblicza. Biskupi podlegli metropolitom w granicach prowincji, sta$1 i$ na czele miast - "civitates". Były to ich siedziby, zalążki późniejszych diecezj1. Wokół nich skupiały się kościoły wiejskie z zanikłymi później chorepiskopami oraz z duszpasterzami, z których wykształc1li się proboszczowie, stojacy na czele parafii ${ }^{6}$.

Na tle zarysu tak ukształtowanej organizacji kościelnej, będzie nam łatwiej śledzić nicejskie postanowienia, okréslające strukturę ustrojową duchowieństwa. Sobór uregulował pięć tego typu zagadnień, a mianowicie:

- konieczność dokładnego przestrzegania hierarchicznych stopni władzy święceń,

- relatywność święceń,

- obsada stanowisk biskupich,

- Instytucja synodów prowinejalnych,

- system wymierzania ekskomunik.

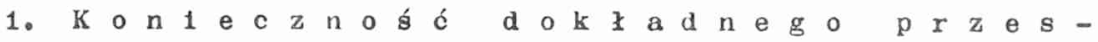

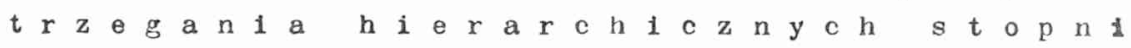

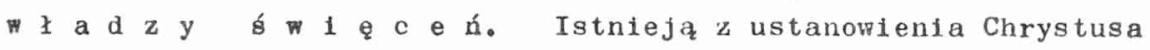
trzy stopnie hierarchiczne władzy święceń: diakonat, prezbiterat, episkopat, z określonymi kompetencjami, zwǎaszcza zaś z wykluczeniem diakonów od sprawowania ofiary eucharystycznej ${ }^{7}$.

Sobór Nicejski I nakazał ściśle przestrzegać tego podziału, zwłaszcza zaś przy rozdzielaniu komunil św., podczas sprawowania najówiętszej ofiary oraz przy zajmowaniu miejsc. Kanon 18 podaje przykłady, 1ż diakon1 udzielają komunil św. prezbiterom, a im samym podaje się eucharystię nawet przed biskupami. Sobór zakazuje więc takiej praktyk1 nawet pod groźbą wykluczenia diakonów od słuźby ołtarza 1 zabrania diakonom udzielania komuni św. prezbiterom

5 I. Jaworski, Zarys powszechnej historit państwa i prawa, Warszaพล $1983,15-18$.

6 W. M. Pl bchl, Geschichte des Kirchenrechts, I, Wien-MUnchen 1953, 51-54.

7 Ks. W. Granat, Dogmatyka katolicka. Synteza, Lublin 1964, 419. 
/a tym bardziej biskupom/, im samym zaś nakazuje ją przyjmować z rąk jednych lub drugich. Nie zezwala też diakonom zajmować miejsca wśród prezbiterów ${ }^{8}$. Chodziło tu oczywiście o liturgię mszy św., przy której według myśli Soboru należało szczególnie ostro zachować podział władzy na trzy stany hierarchiczne. Jest to bowiem akt kultu publicznego, gdzie winien panować porządek ustanowiony przez Jezusa Chrystusa. Przejawił się tu także lęk ojców soborowych o zacieranie granic między porządkiem boskim i ludzkim w Kościele, co w ówczesnej atmosferze błędów ariańskich nabierało szczególnego znaczenia. Praktyka -, usankcjonowana w Nicei zachowała się do dziś w Kościele łacińskim, gdzie przy mszy św. koncelebrowanej sami koncelebransi się komunikują 1 równiez onf podają Komunię św. diakonom. N1e ma jednak surowego zakazu pod tym względem, dlatego w Jakimś specyricznym układzie diakon mógłby zanieść eucharystię koncelebrującemu kapłanowi lub biskupowi /np. gdyby jeden z nich koncelebrował z wózka inwalidzkiego i nie mógł sam podejść do ołtarza/. Sama jednak zasada nłcejska do dziś pozostaje w mocy.

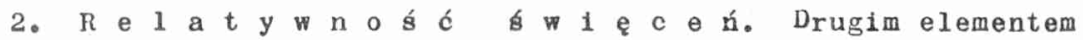
ustrojowyın, jak1 określono w Nice1, była tzw. "relatywność święceń". obecnie istnieje praktyka, że święceń udziela się diakonom, prezbiterom, biskupom na sposób "absolutny", tzn. bez jakiegoś bezwzględnego

8 Canones Concilii Nicaeni 18, Mansi 2, 682-683: "Pervenit ad sanctum magnumque concilium,quod in quibusdam locis et civitatibus, presbyteris gratiam sacrae communionis diaconi porrigant, quod nec regula, nec consuetudo tradidit, ut ab his qui potestatem non habent offerendi, 1111 qui offerunt, Christi corpus accipiant.. Nec non et lilud innotuit, quod quidam diaconi ante episcopos sacra oblata contingant. Haec igitur omnia resecentur, et in sua diaconi mensura permaneant, scientes quod episcoporum quidem ministri sunt, Inferiores autem presbyteris habentur. Per ordinem ergo post presbyteros gratian sacrae communionis accipiant, aut ep1scopo eis, aut presbytero porrigente. Sed nec sedere in medio presbyterorum diaconis liceat: quia si hoc fiat, praeter regulam et ordinem probatur existere. Si quis autem etiam post has definitiones obedire noluerit, a ministerio cessare debebit". Przez "regula et consuetudo", na które się tu Sobór powołuje, należy rozumieć prawo pisane i zwyczajowe. 
uzależnienia wyświęconych od konkretnego urzędu. Wyświęconych włącza się jedynie już przy diakonacie, przez tzw. inkardynację, do jakiejś diecezji, prałatury personalnej lub wspólnoty zakonnej. Jednakze ma on pełne szanse, przy zachowaniı odpowiednich norm pramych, przenoszenta się na różne stanowiska w obrębie tej samej diecezj1, czy nawet z Kościoła partykularnego do wspólnoty zakonnej 1 odwrotnie ${ }^{9}$. Mocniejszym echem dawnej relatywnośc1 święceń jest obecna nominacja biskupów, nawet pomocniczych, związana zawsze z jakąś diecezją, przynajmniej na terenach misyjnych. Fakt ten jednak nie wiąze bezwględnie nominata, gdyz może on być przenoszony na Inne diecezjalne stolice.

W pierwszych wiekach Kościoła istniało natomiast przekonanie, że święcenia są swoistym oddaniem się nie tylko na służbę Bogu 1 ludziom w ogólności, lecz konkretnemu stanowisku kościelnemu, tj. jakiemuś miastu biskupiemu /"civitas episcopalis"/ lub gminie wiernych, a później parafil czy diecezji. Panowało tu przekonanie o swoistych zaślubinach mistycznych zawieranych między wyświęconym a konkretnym kościołem diecezjalnym lub parafialnym, który mu od razu przydzielano zawsze na stałe. Przenoszenia bywały rzadkie, specjalnie umotywowane 1 zawsze w drodze decyzji kompetentnej władzy kościelnej 10 .

Zasadę powyższą, wprowadzoną uprzednio przez prawo zwyczajowe oraz prawo pisane partykularne, mocno osadził w ustroju Kościoła I Sobór Nicejski. Jego 15 kanon postanawiał, ze ze względu na powstające często zamieszania oraz sporł, należy przyjąć za niewzruszoną normę nie przenoszenia się "z miasta do miasta" diakonów, prezbiterów 1 biskupów ${ }^{11}$. Działanie wbrew tej zasadzie Sobór uznał za

9 Por. 265 kanon nowego Kodeksu Prawa Kanonicznego /J a n a $\mathbf{r}$ aw 1 a I I, 1983/; E. Sztafrowski, Podręcznik prawa kanonicznego, I, Warszawa 1985,320 .

10 Por. H. E. Feine, Kirchliche Rechtsgeschichte, dz.cyt., 118; Ch. J. Hefele, Histoire des conciles, dz.cyt., I 1, 600. Praktyka swięceń relatywnych trwała wościele bardzo długo, ustępujazc powoli prawu zwyczajowemu 1 pisanemu partykularnemu. Na skalę ogólnokościelna utorowały drogę śrięceniom absolutnym dopiero postanowienia Stolicy Apostolskiej z lat: 1694, 1894, 1906, a wreszcie upowszechnit ja w formie ustawy ogólnokościelnej Kodeks Prawa Kanonicznego z 1917 r. kan. $111 \S \S 1-2$. Por. P. M. Coronata, Institutiones iuris canonici, I, Torino 1950, $201, \mathrm{n} \cdot 174$.

11 "/.../ de civitate ad civitatem". Wyrażenie "civitas" było wówczas równoznaczne z pojęciem diecezji, gdyź pojęcie i nazwa tej 
nieważne, nakazując duchownemu powrót do kościoła, dla którego został wyświęoony ${ }^{12}$.

$$
\text { 3. } \mathrm{c} \text { b s a d a s t a n o w } 1 \mathrm{~s} k \text { b } 1 \mathrm{~s} k \mathrm{u} \text { p } 1 \text { c h. }
$$

Na początku IV w. był juz mocno zakorzeniony powszechny zwyczaj, że każdy biskup, jako następea Apostołów, posiadał własny okręg terytorialny. Nie były to jeszcze diecezje w ácisłym tego słowa znaczeniu oraz z nazwy, lecz "civitates", tj. miasta. Z tych miejskich biskupów wykształcili się niebawem biskupi diecezjalni ${ }^{13}$. Powstanle formalnych diecezji wyprzedzlła w Kościele organizacja metropolitalna, występująca już w II w., przy końcu III 1 na początku IV w. stała się już powszechną, zarówno wościele wschodnim, jak 1 zachodnim. Metropolici przewodzili okregom zwanym prowincjami, a biskupi na tych terenach podlegali w licznych sprawach ich władzy ${ }^{14}$. Organłzację tę umocnłł właśnie na skalę ogólnokościelną I Sobór Nicejski. Uzależnił on saną obsadę urzędu biskupa od zatwierdzenia metropolity. Konkretnie zaś sobór ustalił następującą procedurę zmierzającą do obsady stanowiska biskupa: 1/ winni go wybrać oraz wyświęcić wszygcy biskup1 prowincj1 ${ }^{15}$; 2/ w wypadku, gdyby niektórzy biskupi nie mogli przybyć na takie spotkanie wyborcze, z powodu waźnej przeszkody osobistej lub zbyt wielkiej odległości, musiało być obecnych przynajmniej trzech, przy założeniu, ze wszyscy nieobecni wyrazili pisemna zgodę na odnośnego kandydata; 3/ wybór 1 święcenia biskupie musiały byé z kolei zatwierdzone

ostatniej przyszły nieco pózniej.Por.W.M. Plochl, dz॰cyt., 52.

12 Canones Concili1 N1caeni 15, Mansi 2, 681-682: "Propter multam perturbationem, et seditiones quae fiunt, placuit consuetudinem omnimodis amputari, quae praeter regulam in quibusdam partibus videtur admissa; ita ut de civitate ad civitatem non episcopus non presbyter, non diaconus transferantur. Si quis autem post definitionem sancti et magni concilii tale quid agere tentaverit; et se huiuscemodinegotio mancipaverit, hoc factum prorsus Irritum ducatur, et restituatur ecclesiae, cuius fuit episcopus, aut presbyter, vel diaconus ordinatus".

13 Por. P. B. Kurtscheid, Historia iuris canonici. Historia Institutorum ab Ecclesiae fundatione usque ad Gratianum, Romae $1951,23-29$.

14 Tamże, 41-42.

15 Canones Concilii Nicaeni 4, Mansi 2, 679: "Episcopum convemu maxime quidem ab omnibus qui sunt in provincia episcopis ordinari". Przez "ordinatio" należy tu rozumieć zarówno wybór, jak $i$ współkonsekrację. Por. P. B. Kurtscheid, dz.cyt., 108. 
przez metropolitę, oczywiście pod rygorem nieważnóci całej procedury ${ }^{16}$. Metropolita brał więc udział w tej akcji dwa razy, raz łącznie z innymi biskupami, wybierając 1 współkonsekrując nowego biskupa, a drugi raz udzielając mu zatwierdzenia/"confirmatio"/ 17 . Postanowienia nicejskie nie wspominaja o procedurze obsady stolicy samego metropolity. Nalezy się domyślać, że wybierali go analogicznie wszyscy biskupi danej prowincji oraz udzielali mu święceń z tym, że nie wymagał on już niczyjego zatwierdzenia.

Uzależnienie obsady urzędów biskupich od metropolity dawało mu równié prawie całkowite zwierzchnictwo nad nimi, łącznie z prawem depozycji. Nie była to zdrowa koncepcja, gdyż stanowisko biskupów pywodzi się z ustanowienia boskiego, jest więc co do swej natury wyższe od kościelno - ludzkiego tworu, jakim jest urząd metropolity. Ponadto odpowiedzialnośc pastoralna biskupów wich diecezjach domagała się 1ch autonomii. Totez odbywała się tu w przyszłości systematyczna ewolucja w kierunku egzempcji biskupów spod władzy metropolitow 18 . Ostatecznie w XIV w. przeszła prowizja, czyli nadawanie urzędów biskupich pod wyłączną kompetencję Stolicy Apostolskiej. W konkordatach 1 różnych porozumieniach z państwami przyznawała ona od tego czasu rózne rodzaje uprawnień i przywilejów do myznaczania /mianowania, prezentowania, wykluczania/ kandydatów na

16 Canones Concili1 Nicaeni 4, Mansi 2, 679: "Si autem hoc diff1cile fuerit, aut propter instantem necessitatem aut propter itineris longitudinem tribus tamen omnimodis in idipsum convenientibus, et absentibus quoque pari modo decernentibus, et per scripta consentientibus, tunc ordinatio celebretur. Firmitas autem eorum quae geruntur, per unamquamque provinciam, metropolitano tribuatur episcopo".

17 Tanże.

18 Już na synodzie regionalnym w Sardyce /343/ doszło do powaźnych ograniczeń kompetencji metropolitów w stosunku do podwładnych $1 \mathrm{~m}$ biskupów. Kanony bowiem 3 i 4 tego synodu przewidywały, jako rzecz zwykłą, apelację biskupów od wyroków swoich metropolitów do Biskupa rzymskiego, nie tylko w wypadkach depozycji lecz wazdej innej sprawie. Było to juź poważe umocnienie pozycji biskupa diecezjalnego, a równocześnie wzmocnienie prymatu papieskiego. Zaczął się tu zbliżać obraz stosunku: papież - biskup - metropolita do wáściwego układu przekazanego przez Jezusa Chrystusa. Na pełne uporządkowanie tego układu nalezało jeszcze długo zaczekać, bo do XIV wieku. Por. Ian Dudziak, Teologiczno - pruwne idee kanonów synodu w Sardyce, TS'T 8/1981/ $339-341$. 
stanowiska biskupóv diecezjalnych ${ }^{19}$.

4. S y n o d y $p$ r w 1 n $j$ a 1 n e. Życte 1 działalność Kościoła w czasach apostolskich zostały ubogacone soborem czy11 spotkaniem wszystkich apostołów odbytym około $50 \mathrm{r}$. w Jerozolimie, na którym podjęto szereg decyzji w żywotnych na owe czasy sprawach ${ }^{20}$. Za jego przykładem weszły w zwyczaj zgromadzenia następców apostołów, tj. biskupów z papieżem na czele, jako wymóg prawa bosko - ludzkiego ${ }^{21}$. Sobór Watykański II był z kolei 21 , nie liczac wspomnianego wyżej Soboru Apostolsíiego. Sobory są w Kościele zawsze jednym z najważniejszym czynników odnowy - reformy, ożywienia w1ary oraz obrony moralności chrześcijańskiej. Stanowia one rzeczywiste przełomy

w powszechnej historil Kościoła.

Ze spontanicznej potrzeby podobne spotkania zaczęli odbywać biskupi na nizszych szczeblach organizacji koscielnej, zwane synodam1 partykularnymi. Najstarszymi z nich były synody prowincjalne, tj. zgromadzenia biskupów danej prowincji pod przewodnictwem metropolity. Ich odmianą były później synody regionalne, gromadzące biskupów jakiegoś regionu, należących do różnych prơrincji22. Były one prototypami późniejszych synodów patriarchalnych, krajowych, prymacjalnych, plenarnych. Wreszcie juz na przełomie starożytności 1 średniowiecza wytworzyły się synody diecezjalne, tj. zgromadzenia

19 P. M. Coronata, dz.cyt., 462-463, n. 393.

$20 \mathrm{Dz} 15,1-35$.

21 Ch. J. Hefele, dz.cyt., I 1, s. 2 .

22 Jest Paktem, ze już II w. gromadzili się biskupi niektórych prowincji celem wspólnych narad odnośnie do wiary 1 obyczajow oraz błędów doktrynalnych 1 herezji. Od III w. synody prowincjalne stały się już reguła w całym ówczesnym Kościele, a więc w Małej Azji, Grecji, Afryce Północnej, Itali1, Galii, Hiszpanil. Pierwszym głośniejszym synodem regionalnym był synod w Sardyce /dzisiejsza Sofia/ w 343 roku. Por.K. Bihlmeyer - H. Ttehle, Kirchengeschichte, Paderborn 1955, I, 111-112, 250, 324-338; Handbuch der Kirchengeschichte, herausg. H. Jedin, Bd. 1: Freiburg-Basel-Wien, I, 1956; K. Baus, Von der Urgemeinde zur Fruhchristlichen Grosskirche, Freiburg 1956, 226, 240, 243, 250, $268,294,311,314,316-317,325,331,350,351,379,397,404$, $407,410,425-429,466$; Bd. 2/1; K. Baus - E. Ewig, Die Reichskirche nach Konstantin dem Grossen, Freiburg 1973, 40, 89, 156 , $216,218,222,237,250-253,281,286,289,290,309,342,345$, $402,417,494$. 
przedstawic1eli duchowieństwa danego Kościoła partykularnego pod przewodnictwem biskupa ${ }^{23}$. Zasada synodalnośc1, utrwalona zwyczajem 1 objęta pózniej prawem pisanym, przyczynia się systematycznie do odnowy także Kościołów partykularnych.

Soborowi Nicejskiemu I znane są tylko synody prowincjalne, które jeśli nie były dotąd wyłączonymi z partykularnych, to w kazdym razie stanowiły lch zasadę oraz główny nurt. Sobór uznał je za bardzo owocne, gdyż nakazał je odbywać w każdej prowincji kościelnej dwa razy w roku ${ }^{24}$. Ponadto wyznaczył tez terminy tym zgromadzeniom, mianowicie, jeden przed Wielkim Postem, a drugi wokresie jesieni ${ }^{25}$. Pierwszy termin został umotywowany w sposób mistyczny słowami: "aby można było złożyé Bogu nieskazitelną ofiarę po usunięciu wszelkiej niezgody". Chodziło tu zapewne o możliwość przeżywania przez wszystkich z czystym i spokojnym sumieniem okresu Wielkiego Postu, po rozstrzygnięciu 1 załatwieniu na synodzie różnych spraw spornych.

Omówiony 5 kanon nicejski, dotyczący synodów prowincjalnych, nie określał całościowo ich przedmiotu, pozostawiając w domniemaniu to zagadnienie kompetencji metropolity oraz podległych mu biskupóm. Sobór jednakże wskazał wybiórczo na jeden problem, który nie mógł być załatwiony gdzie indziej, jak tylko na synodzie. Była to sprawa orzekania kary ekskomuniki. Sankcji tej nie mógł zatem orzekać zaden biskup pojedynczo, lecz była ona zastrzeżona synodowi prowincjalne$\mathrm{mu}^{26}$. Oczywiście takich spraw zastrzeżonych synodowi było więcej, jak

23 Synody diecezjalne w ścisłym tego słowa znaczeniu zaczęto zwoł̀ywać w Kościele dopiero od VI wieku. Do mojego artykułu: Synod diecezjalny, jego struktura i rola wościele partykularnym, "Wrocławskie Studia Teologiczne"16/1984/51, zakradła się nieścisłość, którą pragnę sprostować, a mianowicie, pierwszy znany synod diecezjalny nie odbył sie w $387 \mathrm{r}$. W Rzymie, lecz $\mathbf{w} 585 \mathrm{r}$. w Auxerre. Za te przykrą niescisłośc Drogiego Czytelnika przepraszam. Por. H. E. Feine, dz.cyt., 193.

24 Canones Concilii Nicaeni 5, Mansi 2, 679: "/.../ bene placuit annis singulis per unamquamque provinciam bis in anno concilia ce-
lebrari $/ \ldots / "$.

25 Tamże: "Concilia vero celebrentur unum quidem ante quadragesimam paschae; ut omni dissensione sublata, munus offeratur Deo purissimum; secundum vero circa tempus autumni".

26 Tamże. Por. Ks. M. Myrcha, Ekskomunika, PS 4/1957/ 185-214. Autor nie nawiazuje do waźnych postanowień I Soboru Nicejskiego w sprawie ekskomuniki. Zob., s. 199-200. 
np. wspomniana juz wyżej obsada urzędu biskupa. Sobór po prostu zakładał wiedzę biskupów w tej materii 1 nie wyliczał taksatywnie tzw. spraw synodalnych.

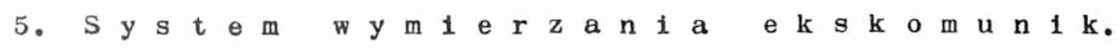
W systemie penitencjarnym $i$ karnym pierwotnego Kościoła zaczęła się kształtować jedna z najdotkliwszych kar, tj. ekskomunika. Miała ona swoje źródło w Ewangelii oraz w nauce i praktyce Apostcłów27. Zaczęły ją też bliżej określać synody pierwszych wieków oraz pisma ojców Kościoła. Precyzowało się więc pojęcie wspólnoty wierzących /"Communio fidelium"/ oraz tych, których należało za określone przestępstwa z tej wspólnoty całkowicie lub częściowo wykluczać /ekskomunikować/. Przy czym znane były już w starożytności różne stopnie wykluczenia oraz odpowiadające im różne sposoby powrotu do wspólnoty 1 jedności z wiernyni ${ }^{28}$.

Omawiany Sobór Nicejski uznał zagadnienie wymiaru ekskomuniki za bardzo doniosłe. Zajął się nim bowiem pieczołowicie i podjął próbę ujednolicenia jej wymiaru. Nie stwierdzamy bliższego określenia tej kary przez ojców Soboru, z czego wynika, iź zagadnienie to było powszechnie znane. Mamy tu tylko procedurę związaną z orzeczeniem tej sankcji.

Jak już wyżej wspomnieliśmy, sam wymiar ekskomuniki, zarówno w stosunku do duchownych, jak i wiernych świeckich, zastrzegł Sobór zgromadzeniu biskupów zebranemu na synodzie prowincjalnym ${ }^{29}$. Ciekawe jest uzasadnierie tej rezerwacji. Chodziło mianowicie o to, by ktoś nie popadł w tak dotkliwą karę z powodu wałoduszności, chęc1 zemsty lub innego błędu, któremu mógł ulec wymierzający tę karę biskup ${ }^{30}$.

27 Por: Mt $18,15-17 ; 1$ Kor $5,1-5$.

28 Por. P.B. Kurtscheid, dz.cyt., 84-88; M. W. Plochl, dz.cyt., 91-93.

29 Canones Concilil Nicaeni 5, Mansi 2, 679: "De his. aui communinne privantur seu ex clero, seu ex laico ordine,ab episcopis per unam quamque provinciau, sententia regularis obtineat".

30 Tanże: "Requiratur autem, ne pusillanimitate, aut contentione, aut alio quolibet episcopi vitio, videantur a congregatione seclusi". 
Dlatego też nałożenıe ekskomunikı winni byli dokładnie przedyskutować wszyscy biskupi zebrani na synodzie ${ }^{31}$. Dopiero po dokładnym 1 dojrzałym przedyskutowaniu sprawy można było orzec tę karę, pod jednym wszakże warunkiem, że wykazano oczywistą winę oskarżonego ${ }^{32}$. Nawet wówczas Sobór podsunął jednak możliwość alternatywnego postępowania, tj. zastosowania czegoś w rodzaju prawa łaski. Stwierdził bowiem, że wobec winnego ekskomuniki mogli albo wszyscy biskupi na synodzie, albo dany biskup, któremu podlegał oskarżony, wydać bardziej humanitarny wyrok ${ }^{33}$. Wreszcie odnośny kanon nicejski określił ubocznie, lecz bardzo przy tym ogólnikowo, skutki ekskomuniki. Ten, kto został nią obłożony, miał być przez wszystkich "odrzucony":

"hi qui abiciuntur ab aliis non recipiantur"34. Chodziło tu zapewne przede wszystkim o to, ażeby po takim wspólnotowym wyroku skazującym ekskomunikowany nie znalazł akceptacji u żadnego pojedynczego biskupa prowincji. Inne skutki tej kary Sobór pominął. Były one powszechnie znane, jak wykluczenie z kultu Bożego oraz izolacja od współżycia $z$ wiernymi.

\section{POWINNOŚCI STANOWE DUCHOWNYCH}

W zalążkach ogólnokościelnej dyscypliny duchowieństwa, jakie stworzył I Sobór Nicejski, istnieje obok wyzej wymienionych zasad strukturalnych, druga grupa norm, a mianowicie kanony zawierające p o w $i \mathrm{n} n$ o śc 1 d u c h o w n y c h. Saz to już zasady odnoszące się nie do całych zjawisk kanonistycznych, czyl1 struktur,

31 Tamże: "Ut hoc ergo decentius inquiratur, bene placuit $/ \ldots /$, ut communiter omnibus simul episcopis provinciae congregatis, discutiantur huiusmodi quaestiones".

32 Tanże: "/.../ et sic, qui suo peccaverint evidenter episcopo, excommunicati rationabiliter ab omnibus aestimentur".

33 Tamże: "/.../ usque vel in communi, vel episcopo placeat humaniorem protalibus ferre sententiam". Chodziło tu najwidoczniej o wzięcie pod uwagę okoliczności łagodzących po stronie przestępcy oraz o wymiar bardziej umiarkowanych form samej ekskomuniki. Odpowiadało to ówczesnym rodzajom tej kary.

34 Tamże. 
lecz do osób fizycznych, tj. duchownych, którzy ze względu na swe powołanie winni prowadzić inny tryb źycia, niż ludzie świeccy. Całkiem tego świadomi byli już ojcowie pierwszego Soboru ekumenicznego z 325 roku. Powinności te można ująć w następujące grupy:

- Pizyczna, duchowa 1 prawna zdatność kandydata do stanu duchownego,

- ochrona prawna wstrzemięźliwości cielesnej i dobrego imienia duchownych,

- postawa duchownych wobec dóbr materialnych,

- rezydencja duchownych w miejscu posługi duszpasterskiej.

$$
\text { 1. Fiz y c z n a, d u c h o w a i p r a n a }
$$

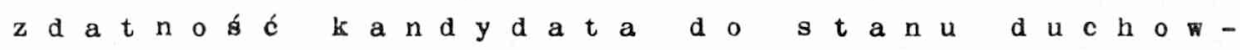
$\mathrm{n}$ e g o. Stawiając określone kryteria zdatności kandydata do stanu duchownego, I Sobór Nicejski już z góry wyznaczał te kwalifikacje, jako powinności, do ktorych miał się dostosować zarówno sam duchowny, jak 1 władza kościelna dopuszczająca go do święceń lub tolerująca go w szeregach duchowieństwa.

Określente $\mathrm{z}$ d a $\mathrm{t} n$ o śs $\mathrm{i} \quad \boldsymbol{f} \mathrm{z}$ y $\mathrm{c} \mathrm{z}$ e $j$ odpowiadało konkretnym warunkom i ówczesnym potrzebom. W świecie pogańskim, w którym rozwijaź się starożytny Kościół istniało wiele obyczajowych okrucieństw. Między innymi stosowanie czy to ze strony panów w stosunku do niewolników, czy też ze strony władzy w stosunku do podwładnych kary okaleczenia ciała, aż do pozbawienia organów męskich włącznie /wytrzebienie/35. Srodkiem tym posługiwano się takze w różnych porachunkach osobistych. Sobór Nicejski I rozpatrzył to zagadnienie pod kątem zdatności kandydatów do stanu duchownego. Jego normy brały pod uwage różne sposoby takiego okaleczenia. Jeżeli mianowicie okaleczenie zostało dokonane dla celów zdrowotnych przez lekarzy lub tez gwałtem przez barbarzyńców, albo przez własnych panów, nie mlało ono żadnych skutków prawnych. Takiego kandydata można było dopuścíc do stanu duchownego, jeśli był on skądinąd tego godny. Gdyby był już duchownym, mógł dalej nim pozostać. Natomiast nie był zdatny do stanu duchownego lub pozostania w szeregach duchowieństwa

35 Por. J. Carcopino, Zycie codzienne w Rymie w okresie rozkwitu cesarstwa, tłum.M. Pqucinska, Warszawa 1966, 67 . 
ten, kto dokonał sam na sobie w sposób swobodny takiego zabiegu ${ }^{36}$. Ta norma nicejska stała się nieodłącznym elementem późniejszej dyscypliny kościelnej 1 w formie ogólniejszej ma swoje zastosowanie także we współczesnym Kodeksie Prawa Kanonicznego ${ }^{37}$.

$\mathrm{D} u \mathrm{c}$ h $\mathrm{O}$ a $\mathrm{z}$ d a $\mathrm{t}$ n ós ć kandydata do stanu duchownego wiązała się w pojęciu I Soboru Nicejskiego z wypróbowaniemi wtwier. dzeniem wierze. Sobór potępił m•in. zakradający się zły zwyczaj, mocą którego zaczęto dopuszczać do prezbiteratu a nawet episkopatu ludzi, którzy zostali ochrzczeni bez odpowiednio zorganizowanego katechumenatu, a po chrzcie nie odbyli jeszcze próby życia chrześcijańskiego ${ }^{38}$. Na przyszłość było konieczne przestrzeganie odpowiednio długiego katechumenatu przed chrztem 1 dłuższego potem ugruntowania w wierze ${ }^{39}$. To postanowienie nicejskie przetrwało również wościele do czasów współczesnych 40 .

36 Canones Concilii Nicaeni 1, Mansi 2, 678: "Si quis a medicis propter languorem desectus est, aut a barbaris abscissus, hic in clero permaneat. Si quis autem seipsum sanus abscidit, hunc et in clero constitutum abstinere convenit, et deinceps nullum debere talium promoveri. Sicut autem hoc claret, quod de his, qui hanc remi affectant, audentque semetipsos abscindere, dictum est: sic eos, quos aut barbari, aut domini castraverunt, si inveniunt alias dignissimi, tales ad clerum suscipit regula".

37 Wśród nieprawidłowości do święceń Kodeks wymienia zakaz przyjmowania święceń lub ich wykonywania przez tych, którzy "poważnie $i$ z rozmysłem zranili samych siebie". Por.kan. 1041, n. 5.

38 Canones Concilii Nicaeni 2, Mansi 2, 678: "Quoniam plura aut per necessitatem, aut alias urgentibus hominibus adversus ecclesiasticam facta sunt regulain, ut homines ex gentili vita nuper accedentes ad fidem et instructos brevi tempore, mox ad lavacrum spiritale perducerent, simulque ut baptizati sunt ad episcopatum vel ad presbyteratum promoverent; optime placuit, nihil tale de reliquo fieri".

39 Tamie: "Nam et tempore opus est ei, qui catechizatur, et post baptismum probatione quam plurima".

40 Wśród tzw. przeszkód zwykłych do świ žceń istnieje dzisiaj również taka, że nie jest do nich zdatny i nie jest dopuszczany "neofita, dopóki wedkug oceny ordynariusza nie został dostatecznie utwierdzony". Por. kan. 1042, n. 3 . 
Przez p $\mathrm{r}$ a w $\mathrm{n}$ ą $\mathrm{z}$ d a $\mathrm{t} \mathrm{n}$ o ś é do święceń Sobór Nicejski rozumiał terytorialna przynaleźność kandydata do danego biskupa. Stąd biskup chcący wyświęciś obcego podwładnego musiał otrzymać zezwolenie jego własnego blskupa $i$ to pod rygorem nieważnośc1 święceń ${ }^{41}$. W łagodniejszej nieco formie, gdyż nie do waźności święceń, lecz do ich godziwości, domaga się tego samego do dzló prawo kanonicz$n e^{42}$.

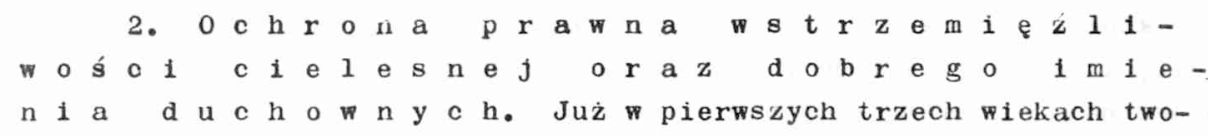
rzyła się w Kościele praktyka celibatu na synodach partykularnych oraz wiśmiennictwie. Celibat rozumiano nie tylko jako bezźeństwo, ale jako pełną, doskonała czystość. Chociaż przyjmowano jeszcze wówczas w szeregi duchowieństwa także żonatych kandydatów, to jednak zakazywano im surowo po otrzymaniu święceń współżycia z żonami, nakazywano zaś wstrzemięźliwość małźeńską 1 w8zelką cielesną ${ }^{4}$. Sobór Nicejski I nie rozstrzygnał wprost zagadnienia celibatu, ponieważ n1e zabronił udzielania święceń żonatym mężczyznom. Natomiast najwyraźniej poparł on celibat w sposób uboczny i faktyczny, bezpośrednio zaś wprowadził coś w rodzaju ochrony prawnej dla cielesnej wstrzemięźliwości oraz dobrego imienia duchownych w tym względzie. Zawiera się to w soborowym zakazie przetrzymywania niewiast w mieszkaniach duchownych, poza matką, siostrą, ciotką oraz ewentualnie kobietami, które wykluczają wszelkie podejrzenia co do niezachowywania czystości ${ }^{44}$. Prawie w dosłownym brzmieniu przechodziła ta przestroga nicejska poprzez późniejsze sobory i synody partykujarne, aż do

41 Canones Concili1 Nicaeni 16 /Gentiano Herveto interprete/, Mansi 2, 675: "Sin autem etian ausus Puerit quispiam eum, qui ad alium pertinet surripere, et in ecclesia non consentiente proprio episcopo, a quo recessit, qui in canone censetur, irrita sit ordinatio".

42 Por. kan. 1015 \$ 1 .

43 Por. F. Lauchert, Die Kanones der wichtigsten altkirchlichen Concilien, Freiburg et Leipzig 1896, 17-19; P. B. Kurtscheid, $\mathrm{dz} . \mathrm{cyt}$., 73-75.

44 Canones Concili1 $\mathrm{N}_{\mathbf{1}}$ caeni 3, Mansi 2, 679: "Interdixit per omnia magna synodus, non episcopo, non presbytero, non diacono, nec alicui omnino qui in clero est, licere subintroductam habere mulierem; nisi forte aut matrem, aut sororem, aut amitam, vel eas tantum personas, quae suspicionem effuglunt". 
Kodeksu Prawa Kanonlcznego z 1917 roku5 . Obecny Kodeks Jana Pawła II sformułował ten obowiązek duchownych nieco ogólniej, lecz zachował samą jego idee, pozostawiając blitszą konkretyzacje w tej sprawie ustamodawstwu partykularnemu 46 .

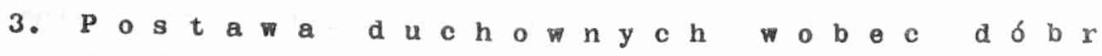
m a $t$ er 1 a 1 n y c h. Dla Koścloła, jako wspólnoty o duchowym 1 nadprzyrodzonym celu, od zarania dzlejów był 1 jest wciąz aktualny problem postawy wobec doczesnych dóbr materialnych. W swej dziaxalnośc1 zbawczej Kościóz od pierwszych wieków stawiał to zagadnienie jasno, a mianowicie uznawał dobra doczesne za konieczne środk1 ewangelizacji, a nie za wartości same wobie $e^{47}$. Istnial jednak zawsze 1 drugi aspekt tego problemu, a była nim konieczność utrzymania duchowieństwa w należytym dystansie duchowym do dóbr doczesnych, tak by zbytnie lub nieuporządkowane icn gromadzenie nie oboiazzało ich duchowości oraz nie utrudniało dawania śviadectwa ewangelicznego ubóstwa.

Zdecydowanie postawiły ten problem omawiane kanony nicejskie。 Nawiązując do niepokojących wówczas faktów przejawiania przez duchomnych chciwości oraz zachlanności materialnej, pożyczania pieniędzy na lichwę 1 ciagnięcia z tego nieuczciwych zysków, Sobór jak najsurowiej zakazal im na przyszłośc tego rodzaju praktyk 1 postaw, niepoprawnym zaś zagroziz sankcją usunięcia z szeregów duchowieństwa. Zakaz ten zwracał się nie tylko przeciwko lichwie jako takiej, tj. poźyczce na wysok1 procent, lecz także przeciwko wszelkim innym, nieuczciwym sposobom zbijania fortuny. Moźna zatem wyciągnąć logiczny wniosek, że została tu określona sama wizja postawy duchownego wobec dóbr materialnych, według której nie powinien on szukać w życiu zysków materialnych, pod jakąkolwiek postacią. Dobra doczesne winien traktować jedynie jako niezbędne środki do swego życia oraz posług 1 pastoralnej 48 . Obowiazek należytego odniesienia

45 Por. Codex Iuris Canonici /1917/ can. $133 \S \S 1-3$.

46 Por. Kodeks Prawa Kanonicznego / 1983/ kan. $277 \S \S 2-3$.

47 Por. M. W. Pl bch1, dz॰cyt., 94-97; H. E. Feine, dz॰cyt., 119-121.

48 Canones Concili1 Nicaeni 17, Mansi 2, 682: "Quoniam multi sub regula constituti, avaritiam et turpia lucra sectantur, oblit1que divinae scripturae dicentis: "Qui pecuniam suam non dedit ad usuram /Ps 6/; mutuum dantes centesimas exigunt; 1uste 
do dóbr materialnych był obecny odtąd we wszystkich ogólnokościelnych zbiorach prawa kanonicznego. Papiez Jan Paweł II umieśc1ł równiez w swym ustawodawstwie tę wytyczną dla duchownych wóród podstawowych obowiązków. Zakazał im więc uprawiania handlu, polecił prowadzió skromne życie oraz przekazywá́ zbywające dobra materialne na cele kośclelne oraz charytatywne 49 .

$$
\text { 4. R e z y d e n c ja d u c h o w n y c h w m i e j- }
$$

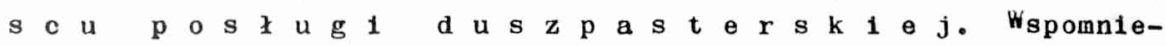
liśmy już wyżej, przy ustrojowych elementach dyscypliny duchowleństwa, o relatywności święceń w starożytności chrześcijanskiej ${ }^{50}$. Dopowiedzmy tutaj, że relatywność ta rodziła specjalną 1 osobową powinność prawną duchownych, w wyniku której musielt oni rezydować przy kościele, dla którego zostali wyświęceni; biskupi w swoim mieście biskupim, prezbiterzy i diakoni w gminie 1 parafii, dla których zostali przeznaczeni przy święceniach. Sobór Nicejski I podkreślił mocno obowiązek przebywania duchownych w miejscu ich posługi pastoralnej, chociaż nie użył słowa "rezydencja". Z redakcji 15 kanonu poświęconego temu zagadnieniu wynika jasno intencja Soboru. Wielu duchownych zaczęło się angażować w pracę innych kośc1ołów, stąd powstawały "perturbationes et seditiones"/zamieszania 1 spory/. Dlatego też Sobór uchylił oraz potępił ten niewłaściwy zwyczaj oraz surowo nakazał, by duchowni trzymali sie własnych kościołów, bez względu na to, czy to byli biskupi, prezbiterzy czy diakoni ${ }^{51}$. Chociaż później zarzucono wościele koncepcję święceń relatywnych, to jednak pozostała na trwałe w dyscyplinie kościelnej zasada rezydencji duchownych, piastujących wazniejsze stanowiska

censuit sancta et magna synodus, ut si quis inventus fuerit post hanc definitionem usuras accipiens, aut ex adinventione aliqua, vel quolibet modo negotium transigens, aut hemiolia, id est sescupla exigens, vel aliquid tale prorsus excogitans turpis lucri gratia; dejiciatur a clero et alienus existat a regula". Por. J. Majka, Stanowisko chrześcijaństwa wobec lichwy w starożytności i wczesnym średniowieczu, RTK 10/1963/ $\mathrm{z} .2,81$.

49 Por. kan. $282 \S \S 1-2 ; 286$.

50 Por. priypis 9-11.

51 Por. przypis 12 . 
duszpasterskie, jak np. proboszcz, biskup 52 .

Sobór Nicejski I nie zawarł w swych kanonach całej, znanej juź ówczesnemu Kościołowi dyscypliny duchowieństwa. Poruszył jednak bardzo szeroki zakres zagadnień z tej dziedziny. Daje to wyraz bogatej świadomości eklezjalnej tamtejszych ojców soborowych. Większość tych zjawisk dyscyplinarnych zadomowiła się na stałe w powszechnym ustawodawstwie kościelnym i przetrwała co do substancji aż do naszych czasów, przechodząc jednak zrozumiałą ewolucję. Jedne z tych zagadnień dyscyplinarnych wchodzą w samą strukturę stanu duchownego jako takiego. Ustawił je Sobór Nicejski na płaszczýnie ustrojowej całego Kościoła. Należą tu: trzy stopnie hierarchil władzy święceŕ /diakonat, prezbiterat, episkopat/, relatywność święcé́, czyli przywiązanie duchownych do konkretnych stanowisk, tj. kosciołów; obsada stanowisk biskupich oparta o biskupów prowincji oraz władzę metropolity; ustabilizowanle się synodów prowincjalnych; wreszcie system wymiaru oraz obowiızzywania ekskomunik.

Druga kategoria nicejskich zagadnień dyscypliny duchowieństwa dotyczyła osobowych powinności duchownych. Sobór Nicejski przekazał tu w spuściźnie Kościołowi takie ważkie określenia, jak kwalifikacj‘ kandydatów do stanu duchownego, ochrona prawna wstrzenięźliwośc1 cielesnej oraz dobrego imienia duchownych, postawa duchownych wobec dóbr materialnych, w końcu rezydencja duchownych w miejscu ich posługi pastoralnej.

Byłoby rzeczą interesującą prześledzenie tej problenatyki w jej późniejszej ewolucji historycznej. Wymaga to jednak już oddzielnego studium.

\section{Ks. Jan Dudziak - Tarnów}

DIE WURZELN DEH KIRCHLICHEN DISZIPLIN DES GEISTLICHEN " STANDES IM LICHTE DES ERS'TEN OKUMENISCHEN KONZILS ZU NIZÄA /Zus ammenfassung/

Der Verfasser beschreibt in dem Artikel die Hauptstaze der Berufs. pelichten der Geistlichkeit nach den Beschlussen des okumenischen Konzils zu Nizal im Jahre 325. Das Frageproblem steht darin, dass jene disziplinelien Pflichien PUr die Geistlichkeit zum ersten Mal

52 Por. Kodeks Prawa Kanonicznego / 1983/ kan. $395 \S \S 1-2 ; 533$ $\S 81-3$. 
darals wie ein allgemeines Kirchenrecht verfasst wurden.

Im Konkreten gehørten dazu zwel Kategorien der rechtsdisziplinarischen Regeln. Vor allem waren es jene, die auch der allgemeinen kirchlichen Verfassung gebuhrende Grundrisse bildeten, und zwar: 1/ die hierarchischen Grade der Weihemacht /des Diakonats, Priestertums, Bistums/; 2/ die Relativitat des damaligen Weihesystems; $3 /$ die Besetzung der Bischøfe nach der kirchlichen Auffassung; 4/ die Regelmassige Haltung der Provinzialsynoden; 5/ die richtige Anwendung der Exkommunikationsstrafen.

Zur zweiten Kategorie sollen dagegen jene Konzilsbeschlusse zu Nizba gezehlt werden, mit denen man vielmehr personale Pflichten der Geistlichkeit bestimnt hatte, un nomlich: 1/ die physische und morale Flhigkeit der Kandidaten zur Priesterweihe; 2/ der Rechtsschutz ftur das Zolibat und fur den guten Puf der geistlichen Personen; $3 /$ eine Grundstellung der Geistlichkeit gegen den Wohlstand wie auch derer Residenzplicht bei den Pastoralposten. 